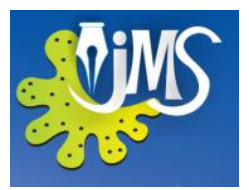

\title{
Silicon Supplementation by Rice Hull Leachate on the Growth, Yield, Fruit Parameters and Anthracnose Disease Resistance of Capsicum 'MuriaF1'
}

\author{
H. A. R. K. Jayawardana ${ }^{1}$, H. L. D. Weerahewa ${ }^{1}$ and M. D. J. S. Saparamadu ${ }^{2}$ \\ ${ }^{1}$ Department of Botany, Faculty of Natural Science, Open University of Sri Lanka \\ ${ }^{2}$ Department of Chemistry, Faculty of Natural Science, Open University of Sri Lanka
}

\begin{abstract}
Silicon has prooven beneficial in growth, yield and disease resistance of plants. Currently, the different chemical sources; sodium silicate, potassium silicate and calcium silicate have been used to supply Si for plants. However, rice hull is one of the natural sources of Si which has not properly utilized. It has been reported that $5 \mathrm{~g}$ of rice hull leach $40 \mathrm{ppm}$ of soluble Si in a week of soaking period. Thus, this research was conducted to investigate the effect of rice hull leachate as a Si source, on growth, yield and fruit parameters and also disease resistance of hydroponically grown Capsicum annum L. 'Muria F1'. Leaching studies were conducted to determine the optimum level of Si leached by rice hull, by soaking them in different time periods (days). This leachate was incorporated to the plants grown in hydroponic media supplemented with two different nutrient solutions i.e Nutrient formula (NF) and Albert solution. The growth, yield and fruit quality parameters were measured and the resistance against anthracnose disease was assessed by artificial inoculation of fruits with Colletotrichum gloeosporioides and measuring the lesion area. Capsicum plants grown in rice hull leachate with either nutrient solution showed significant increase in, shoot length (>12\%), number of leaves $(>27 \%)$, leaf area $(>42 \%)$ fruit length $(>12 \%)$, fruit fresh weight $(>37 \%)$ and yield $(>44 \%)$ and also a significant reduction of anthracnose disease (>43\%) compared to control. The results revealed that rice hull leachate could be used as a low cost silicon source in hydroponic media to enhance performance of Capsicum cv. Muria F1.
\end{abstract}

Keywords: Rice hull, Capsicum annum L., silicon, Colletotrichum gloeosporioides, hydroponic. 


\section{INTRODUCTION}

Capsicum (Capsicum annum L.) is a vegetable which fetches a high demand both in local and export market. Anthracnose is one of the major fungal diseases of Capsicum annum L. causing higher postharvest losses [1].The control of disease is currently achieved by application of fungicides, which is costly and environmentally hazardous. Growing capsicum in the field involves extensive labor and a high cost of agrochemicals such as, mineral fertilizers and fungicides in order to assure good yield and quality. Silicon supplementation in plants has been reported to be beneficial on growth, yield, and disease resistance in both monocot and dicot plants. The most promising results were recorded in powdery mildew reduction in cucumber with significant increase in the fresh weight per unit area and chlorophyll content and RUBP carboxylase of leaves as well [2]. In addition, Si plays an important role in mineral nutrition, mechanical strength and abiotic stresses [3]. Hydroponic is a suitable system of growing crops in which space, fertilizer and labor are efficiently used. In case of hydroponic systems, plants are grown in soilless substrates which often supply limited amount of plant available silicon. Different sources of soluble $\mathrm{Si}$ have been used for amendment of nutrient solutions of hydroponics such as sodium silicate [4], potassium silicate [2], calcium silicate [5] etc. Addition of $\mathrm{Si}$ as a soluble silicate into hydroponic nutrient solution would be costly. Rice hull is an agricultural byproduct which is not utilized properly and is readily available which contains about $20 \%$ of silica [6]. It has been reported that $5 \mathrm{~g}$ of rice hull leach $40 \mathrm{ppm}$ of soluble Si in a week of soaking period [7]. Rice hull leachate would be a natural and environmental friendly $\mathrm{Si}$ source to be applied into hydroponic media. However, the effect of leachate may differ with the type of hydroponic nutrient solution.

Objective of this research was to investigate the effect of rice hull leachate supplied with two nutrient solutions; Albert solution and NF nutrient solution on the growth, yield, fruit quality parameters and also resistance against anthracnose disease of Capsicum 'Muria F1'.

\section{MATERIALS AND METHODS}

\subsection{Leaching Study}

Laboratory experiments were conducted to find the concentration of silicon leached by different masses of rice hull soaked in different volumes of tap water for different time periods. Solution samples were analyzed for molybdo reactive silica using a colorimetric method [8]. The optimum conditions which produce highest level of $\mathrm{Si}$ in the leachate was selected according to the results of leachate study.

\subsection{Plant material}

Seeds of Capsicum 'Muria F1' (East-West seed International Ltd of Thailand) were sown on coir dust and compost medium (1:1). Plants were maintained in the nursery for six weeks. Healthy plants were transferred to non circular hydroponic system in a mesh house in $28-30^{\circ} \mathrm{C}$ temperature and $80-85 \%$ relative humidity.

\subsection{Treatments and experimental design}

Two nutrients solutions were used in the experiment; Albert (Unipower (pvt) Ltd.) and NF nutrient solution [7]. Four treatments were 
conducted seperately as Leachate in Albert media (Leachate/AL), Only Albert media (Control/AL), Leachate in NF media (Leachate/NF), Only NF media (Control/NF). The nutrient solution of both treatments was renewed once a week. Treatments were arranged in Complete Randomized Design (CRD) with three replicates having four plants per replicate. The experiment was repeated and the data were analyzed using one way ANOVA in Minitab 14 statistical software.

\subsection{Measurement of growth, yield and fruit quality parameters}

Growth parameters. The shoot length, root length, number of leaves, average leaf area and number of fruits were recorded and data were averaged.

Fruit parameters. Fruit length and fruit fresh weight of each harvested fruit were measured and averaged. Three fruits from each treatment were used to test each fruit quality parameters. Fruit width and fruit pericarp thickness were measured by a vernier caliper. Diameter at the maximum width was taken as the fruit width. Fruits were cross sectioned at the maximum width and 3 measurements of pericarp thickness were taken per cross section. A known weight of fresh fruit was oven dried at $80^{\circ} \mathrm{C}$ for $72 \mathrm{hrs}$ and the dry weight was measured. Fruit firmness was measured by penetrometer (Model FT 40, Wagner Instruments, Greenwich CT). Fruit extracts were prepared by crushing the fruits separately using a blender and squeezing the pulp through a muslin cloth. Total soluble solids (TSS) of fruit extracts were measured by a refractometer (Model WZ-113, China) within the range of 0$32 \%$ Brix and $\mathrm{pH}$ of the extracts was measured using pH meter (Model IQ150, USA). Aliquots
$(5 \mathrm{ml})$ of fruit extracts were titrated against 0.1 $\mathrm{M} \mathrm{NaOH}$ in the presence of phenolphthalein as an indicator and titratable acidity (\%TA) for each sample was determined according to Askar and Trepow [9].

\subsection{Pathogen identification and isolation}

C. gleosporioides was isolated on PDA (Potato Dextrose Agar) media from an anthracnose lesion on capsicum fruit, followed by surface sterilization with $1 \% \mathrm{NaOCl}$ for 1 minute. The tissues were then placed on PDA media and incubated at $27-30^{\circ} \mathrm{C}$. Culture plates were observed for mycelium growth, morphology of culture medium and shape of conidia through light microscope.

\subsection{Assessment of anthracnose disease resistance}

Resistance against anthracnose disease was assessed by artificial inoculation of $C$. gloeosporioides on fruits and measuring the lesion area for 10 days. Six fruits from each treatment were used for the inoculation study. A spore suspension $\left(10^{5}\right.$ conidia per $\left.\mathrm{ml}\right)$ was prepared by using 7days old pure cultures of $C$. gloeosporioides and three drops of spore suspension $(20 \mu \mathrm{l})$ were placed per fruit. Inoculated fruits were maintained in moist chambers (95-100\% relative humidity) at $28 \pm 2$ ${ }^{\circ} \mathrm{C}$ for 10 days. The average lesion area was calculated for each fruit.

\section{RESULTS AND DISCUSSION}

The highest concentration of Si (5 ppm) was found in the leachate produced by $2-3 \mathrm{~kg}$ of rice hull [Fig.1]. Therefore the leachate was prepared by soaking $2 \mathrm{~kg}$ of rice hull in 501 of water for 2 days. 


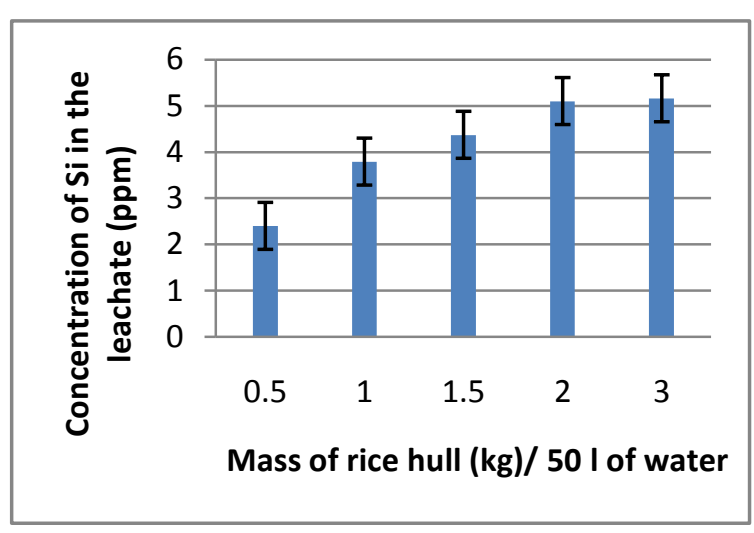

Fig. 1. Different amounts of $\mathrm{Si}$ leached by different masses of rice hull in 501 of water.

The plants treated with rice hull leachate showed significant increase in some important growth, yield and fruit quality parameters compared to control. [Table 1]. Capsicum plants of Leachate/AL treatment showed a significant increase in fruit fresh weight (46\%), fruit length (12\%), shoot length (12\%), no: of leaves $(27 \%)$ and leaf area $(42 \%)$, resulting $46 \%$ increase of per plant yield compared to Control/AL. Similarly, plants of Leachate/NF treatment showed a significant increase in fruit fresh weight $(37 \%)$, fruit length $(17 \%)$, shoot length (15\%), no: of leaves (29\%) and leaf area (44\%), resulting $44 \%$ increase of per plant yield compared to Control/NF.

Table 1. Growth, yield and fruit quality parameters of Capsicum plants treated and non treated with rice hull leachate. Means followed by same letters in each row under each nutrient type are significantly different compared to each control $(\mathrm{P} \leq 0.05)$. Values in parentheses represent percentage increase observed in corresponding parameters compared to each control.

\begin{tabular}{|c|c|c|c|c|}
\hline Parameter & Leachate/AL & Control/AL & Leachate/NF & Control/NF \\
\hline Shoot length $(\mathrm{cm})$ & $77.00^{\mathrm{a}}(12 \%)$ & $69.00^{\mathrm{b}}$ & $75.00^{x}(15 \%)$ & $65.00^{y}$ \\
\hline Root length (cm) & $20.67^{\mathrm{a}}$ & $20.00^{\mathrm{a}}$ & $20.00^{\mathrm{x}}$ & $19.20^{\mathrm{x}}$ \\
\hline No:of leaves & $80^{\mathrm{a}}(27 \%)$ & $63^{\mathrm{b}}$ & $70 \times(29 \%)$ & $54^{\mathrm{y}}$ \\
\hline Avg leaf area $\left(\mathrm{cm}^{2}\right)$ & $68^{\mathrm{a}}(42 \%)$ & $48^{b}$ & $65^{\mathrm{x}}(44 \%)$ & $45^{y}$ \\
\hline $\begin{array}{l}\text { Number of fruits per } \\
\text { plant }\end{array}$ & $10^{\mathrm{a}}$ & $08^{\mathrm{a}}$ & $09^{\mathrm{x}}$ & $09^{\mathrm{x}}$ \\
\hline Fruit length $(\mathrm{cm})$ & $14.58^{\mathrm{a}}(12 \%)$ & $13.01^{\mathrm{b}}$ & $13.70^{\mathrm{x}}(17 \%)$ & $11.75^{\mathrm{y}}$ \\
\hline Fruit width (cm) & $2.75^{\mathrm{a}}$ & $2.69^{\mathrm{a}}$ & $2.67^{\mathrm{x}}$ & $2.73^{x}$ \\
\hline $\begin{array}{l}\text { Fruit pericarp thickness } \\
(\mathrm{mm})\end{array}$ & $3.9^{\mathrm{a}}$ & $3.9^{\mathrm{a}}$ & $4.1^{\mathrm{x}}$ & $4.0^{\mathrm{x}}$ \\
\hline Fruit fresh weight (g) & $35.64^{\mathrm{a}}(46 \%)$ & $24.39^{b}$ & $34.7^{\mathrm{x}}(37 \%)$ & $25.4^{\mathrm{y}}$ \\
\hline $\begin{array}{l}\text { Fruit dry weight (g) per } \\
100 \mathrm{~g} \text { of fresh weight }\end{array}$ & $4.84^{\mathrm{a}}$ & $4.81^{\mathrm{a}}$ & $4.82^{\mathrm{x}}$ & $4.79^{\mathrm{x}}$ \\
\hline$\%$ Titratable acidity & $0.52^{\mathrm{a}}$ & $0.52^{\mathrm{a}}$ & $0.54^{\mathrm{x}}$ & $0.54^{\mathrm{x}}$ \\
\hline $\begin{array}{lll}\text { Total } & \text { Soluble } & \text { Solids } \\
\left({ }^{\circ} \text { Brix }\right) & & \end{array}$ & $7.3^{\mathrm{a}}$ & $7.4^{\mathrm{a}}$ & $7.4^{\mathrm{x}}$ & $7.5^{\mathrm{x}}$ \\
\hline Fruit firmness $(\mathrm{N})$ & $22.53^{\mathrm{a}}$ & $22.23^{\mathrm{a}}$ & $20.9^{\mathrm{x}}$ & $19.6^{\mathrm{x}}$ \\
\hline $\mathrm{pH}$ & $5.72^{\mathrm{a}}$ & $5.65^{\mathrm{a}}$ & $5.00^{\mathrm{x}}$ & $5.50^{\mathrm{x}}$ \\
\hline Yield per plant (g) & $338.76^{\mathrm{a}}(46 \%)$ & $231.36^{b}$ & $324.5^{\mathrm{x}}(44 \%)$ & $225.85^{y}$ \\
\hline
\end{tabular}


It was reported that the growth of rice was enhanced by the addition of $\mathrm{Si}$ to the nutrient solution [10]. Improvements in plant yield due to $\mathrm{Si}$ application have been reported in sugarcane [11] and cucumber [2] also. It has been reported that omission of the $\mathrm{Si}$ causes deficiency symptoms in tomato [12] and cucumber [13] and marked adverse effects as well on soybean [14] and strawberry [15]. The current study also suggests the importance of adding silicon in to nutrient solution of hydroponics system.

However, there was no significant effect of leachate supplement on average number of fruits per plant, root length, fruit width, pericarp thickness, fruit dry weight, titratable acidity, total soluble solids, $\mathrm{pH}$ and fruit firmness [Table1].

In addition, the harvested fruits from plants treated with rice hull leachate (Leachate/AL) showed a significantly lower lesion area $\left(52.77 \mathrm{~mm}^{2}\right)$ at 10 days after inoculation compared to control $\left(96.10 \mathrm{~mm}^{2}\right)$ (Fig. 2.) showing a $45 \%$ reduction of anthracnose disease compared to Control/L. In the same way, fruits of Leachate/NF (58.33 $\mathrm{mm}^{2}$ ) showed a significantly lower lesion area compared to Control/NF (103.87 $\mathrm{mm}^{2}$ ) (Fig. 2.) with a disease reduction of $43 \%$. It has been reported that silicon reduced anthracnose disease significantly in sorghum [16], cucumber [17], beans [18] and tomato [19].

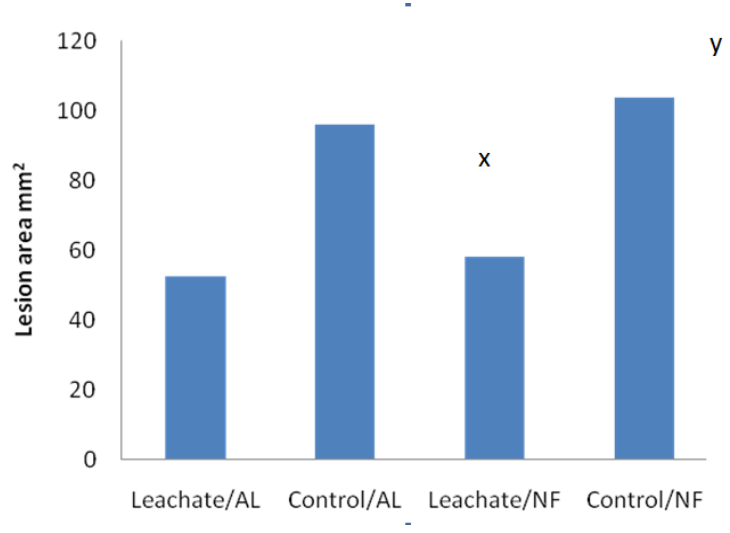

Fig.2. Average lesion area of fruits at 10 days after inoculation $C$. gloeosporioides.

The rice hull leachate applied in this experiment contained $5 \mathrm{ppm}$ of soluble $\mathrm{Si}$. It could be suggested that increased concentrations of $\mathrm{Si}$ in the rice hull may possibly increase the disease resistance. In the current study, it was practically difficult to increase the mass of rice hull and the soaking duration due to the bad odour created. Further studies would be needed to test different techniques and application methods in hydroponic systems in order to leach more silicon by rice hull.

\section{CONCLUSION}

Silicon has beneficial effects on Capsicum plants grown in hydroponics system and it was revealed that, rice hull leachate is a cost effective silicon source for hydroponic systems either in Albert or NF nutrient solution to enhance the yield, some growth parameters and anthracnose disease resistance of Capsicum annum L. 'Muria F1'. 


\section{REFERENCES}

OANH, L.T.K., KORPRADITSKUL, V., RATTANAKREETAKUL, C.A (2004). pathogenicity of Anthracnose Fungus, Colletotrichum capsici on Various Thai Chili Varieties. Kasetsart Journal (Natural Science). 38, 103--108

ADATIA, M.H. BESTFORD, R.T. (1986). The Effects of Silicon on Cucumber Plants Grown in Recirculating Nutrient Solution. Ann. Bot. 58, 343--351

EPSTEIN, E. (1993). Review-The anomaly of silicon in plant biology. proc. Natl.Acad.Sci. USA.91, 11--17

HUANG, C., ROBERTS, P.D., DATNOFF, L.E. (2011). Silicon Suppresses Fusarium Crown and Root Rot of Tomato. J Phytopathol. 159, 546--554

FRENCH-MONAR, R.D., RODRIGUES, F.A., KORNDORFER, G.H., DATNOFF, L.E. (2010). Silicon Suppresses Phytophthora Blight Development on Bell Pepper. J.Phytopathology, 58, 554--560

MAMPITIYARACHCHI, T.R. (1980). Use of Rice Hull Ash in Water Treatment.: Phd thesis. The University of New South Wales. SAPARAMADU M.D.J.S. (2008). Development of a User Friendly and Cost Effective Nutrient Management Strategy for Simplified Hydroponics.: Mphil thesis. pp. 293.

CLESCERI, S.L., GREENBURGE, A.E., EATON, A.D. (eds). (1998). Standard Methods for the Examination of Water and Waste Water. (20 ${ }^{\text {th }}$ ed.). American public health association. United book press. Baltimore. Maryland.

ASKAR, A., TREPOW, H. (1993). Quality Assuarance in Tropical Fruit Processing. Springerverlay, New York. pp.9--25.
MA, J., TAKAHASHI, E. (1989). Effect of Silicon on the Growth of Rice Plant at Different Growth Stages.jpn.J.Soil Sci. Plant Nutr. 35, 347--356

ELAWAD, S.H., GASCHO, G.J., STREET, J.J. (1982). Response of Sugarcane to Silicate Source and rate I: Growth and Yield Agron J.74, 481--484

MIYAKE, Y., TAKAHASHI, E. (1978). Silicon Deficiency of Tomato Plant. Soil Sci. Plant Nutr. 24, 175--189.

MIYAKE, Y., TAKAHASHI, E. (1983). Effect of Silicon on the Growth of SolutionCultured Cucumber Plants. Soil Sci. Plant Nutr. 29, 71--83.

MIYAKE, Y., TAKAHASHI, E. (1985). Effect of Silicon on the Growth of Soybean Plants in a Solution Culture. Soil Sci Plant Nutr. 31, 625--636.

MIYAKE, Y., TAKAHASHI, E. (1986). Effect of Silicon on the Growth and Fruit Production of Strawberry Plants in a Solution Culture. Soil Sci Plant Nutr. 32, 321--326

NARWAL, R.P. (1973). Silica Bodies and Resistance to Infection in jowar (Sorghum vulgare perc.).Agra Univ J. Res. Sci. 22, $17--20$

KANTO, T. (2002). Research of Silicate for Improvement of Plant Defense Against Pathogens in Japan. In: Second Silicon in Agriculture conference,T. Matoh. (ed.) Press-Net. Kyoto.Japan.pp. 22--26

POLANCO, L.R., RODRIGUES, F.A., NASCIMENTO, K.J.T., SHULMAN, P., SILVA, L.C., NEVES, F.W., Vale, F.X.R. (2012). Biochemical Aspects of Bean Resistance to Anthracnose Mediated by Silicon. Ann App Biol. 161, 140--150

DAVID, D., WEERAHEWA, H.L.D. (2012). 
Silicon Suppresses Anthracnose Disease in Tomato (Lycopersicum esculentum) by Enhancing Disease Resistance. In: Annual academic sessions. Open university of Sri Lanka. 210--214 